\title{
Translation of Personification Majas in the Poetry of Indonesian Language into English (Analysis of Contents of 5 Poems in June Rain by Sapardi Djoko Damono in Before Dawn by John H. McGlynn)
}

\author{
Fauzy Astuti $^{1{ }^{* *}}$, Aceng Rahmat ${ }^{2}$, Rahayu Surtiati Hidayat ${ }^{3}$, Adi Apriadi Adiansha ${ }^{3}$ \\ ${ }^{1}$ Applied Linguistics, State University of Jakarta, Jakarta, Indonesia \\ ${ }^{2}$ Language Education, State University of Jakarta, Jakarta, Indonesia \\ ${ }^{3}$ Department of Linguistics Education, State University of Jakarta, Jakarta, Indonesia \\ *Corresponding author: fauzyastuti@ymail.com
}

Received November 23, 2018; Revised December 27, 2018; Accepted January 15, 2019

\begin{abstract}
The objective of this research is to show to the reader about the tanslation techniques of personification in poem. It is a content analysis in a qualitative methodology. The data of this research are personification sentences in Indonesian poems and its translation in English. This research used a comparative analysis to analize the data of both languages. The researcher compared the poems translation and its source language. The data analyzing leads to find the translation techniques and methods used by the translator. The findings of this research shows that the techniques used by the translator are amplification, transposition, and reduction. Meanwhile the method used by the translator is literal.
\end{abstract}

Keywords: personification, poem, technique, and method

Cite This Article: Fauzy Astuti, Aceng Rahmat, Rahayu Surtiati Hidayat, and Adi Apriadi Adiansha, "Translation of Personification Majas in the Poetry of Indonesian Language into English (Analysis of Contents of 5 Poems in June Rain by Sapardi Djoko Damono in Before Dawn by John H. McGlynn)." American Journal of Educational Research, vol. 7, no. 1 (2019): 64-68. doi: 10.12691/education-7-1-10.

\section{Introduction}

Community interest in literature, both local literature, and international literature is increasing, making the activity of translating literary works even higher. George Steiner the ranslation as a model of human communication, whether it be in one language or between languages when he declares that all acts of communication are acts of translatio [1,2,3]. The opinion explains that all acts of communication, whether one language or between languages are acts of translation. Furthermore, Newmark said that translating is rendering the meaning of a text into another language in the way the author intended [4-10]. A process of transferring the meaning of a text from one language to another as intended by the text writer.

The problem faced is that translating literary works is not the same as translating ordinary texts, special knowledge is needed to get good translation results. Today poetry is one of the most sought-after literary works. However, translating poetry is still considered difficult. Why is that? Poetry is an expression of one's feelings, whether feeling happy, sad, angry or feeling disappointed, which is packaged in a series of words that are considered to represent the feelings of the author [11-15]. The words in poetry are usually beautifully arranged. The beauty in the poem is built by verse, rhyme, and rhythm. In addition, poetry also uses many figurative languages. The many elements that build beauty in poetry are what causes the level of difficulty in translating poetry higher than other literary works.

Some experts say that translating poetry is effective and accurate to be virtually impossible. It is generally accepted that poetry translation involves more difficulties than any other form of translation. Although the text of economic, legal, technical or any other scientific nature can be rendered faithfully and the message is conveyed precisely, translation, and even literal translation is possible. On the other hand, it is almost impossible to render subtle meaning and the cultural and aesthetic connotations hidden in literary works. As a result, some translators, tend to be faithful in style while others focus exclusively on the correct choice of words [16,17].

Translating poetry is different from translating other types of text. Besides meaning, the translator must also consider the form of poetry. Considering meaning and form together is not an easy thing to do. Therefore some translators have a focus on maintaining form, while others focus on the content or meaning of poetry. Regarding this, Nida and Taber said that translation is an attempt to recreate the message in Source Language into Target 
Language with a reasonable equivalent that is as close as possible, first in terms of meaning and then the language style [18]. In translating literary works, the translator must know and apply the rules of translation of literature, so that the values and feelings in the Source Text are conveyed in the Target Text.

\section{Method}

This research refers to the method of translating poetry proposed by Lefevre. Lefevre (in Bassnett-McGuire) mentions that there are seven methods that can be used in translating poetry, namely phonemic translation, literal translation, metric translation, translation of poetry-prose, translation of poetry, free verse translation, and interpretation. Based on Lafever's opinion, an interpreter can emphasize the results of the translation whether it tends to mean or style.

The results of the study show that the method used by the translator is a literal method, the translator translates word by word from Source Language into Target Language. Here is an example of a literally translated poem fragment:

\begin{tabular}{l} 
Source Text \\
BERJALAN DIBELAKANG JENAZAH \\
Berjalan dibelakang jenazah anginpun reda jam mengerdip tak terduga \\
betapa lekas siang menepi, melapangkan jalan dunia di samping: pohon \\
demi pohon menundukkan kepala diatas: matahari kita, matahari itu juga \\
jam mengambang diantaranya tak terduga begitu kosong waktu \\
menghirupnya. \\
Target Text \\
WALKING BEHIND THE BODY \\
$\begin{array}{l}\text { walking behind the body wind subsides hours blink with unexpected } \\
\text { speed the afternoon slips away, broadening earth's roads at the side: tree } \\
\text { after tree bows its head above: our sun, that same sun too hours floating } \\
\text { somewhere in between how unexpectedly empty when breathing them in }\end{array}$ \\
\hline
\end{tabular}

In translating poetry above, the translator tried to find the equivalent of Source Text poetry in the poem Target Text . In terms of rhyme, the Source Text and Target Text look different but the Source Text and Target Text rhythms are the same. The structure of phrases and sentences in the Source Text also looks different from the Target Text structure but the Target Text meaning still feels close to the meaning in Source Text. Thus, although translated literally, the meaning of Source Text can still be conveyed in Target Text. This can be caused by the choice of words in Source Text poetry so simple that when translated the word does not experience meaningful changes in meaning.

\section{Results}

Based on the data obtained, amplification ranks first with 18 uses, followed by transposition with 11 times the use and subsequent reduction with 6 times the use. Next is a presentation on the use of these techniques.

\subsection{Amplification}

In this study, of the 15 personification assemblies gathered, 18 translations were found using amplification or addition techniques. Below is an example of using the amplification technique and discussion.

\begin{tabular}{|c|c|}
\hline Source Text & Target Text \\
\hline Hours flicker (P.1: B.2) & Hours blink \\
\hline
\end{tabular}

The word clock according to KBBI online means: 1 . a time meter (watch, wall bell), 2. a long time, 3. time; when The time referred to in the poem is time; The fragment of the poem that reads Clock flicker can be interpreted as the time that continues to run which is likened to a blinking eye. The translator uses an amplification technique to translate the personification sentence in the fragment of the poem. Use of the technique is considered appropriate. The addition of the letter "s" to the word hour is used to indicate that hour means time, meaning plural because it is impossible for only one time to be meant by a poet. In English to indicate plural objects, it is necessary to mark "s".

\subsection{Transposition}

Of the 15 personification assemblies gathered, 10 translations were found using the transposition technique. Below is an example of using the transposition technique and its discussion.

\begin{tabular}{|c|c|}
\hline Source Text & Target Text \\
\hline Afternoon pulled over (P.1: B.2) & The afternoon slips away \\
\hline
\end{tabular}

The word pulled over in the Source Text turns into a slips away phrase in the target language. Use of the transposition technique to translate the personification sentence above right. Translators translate according to the norms in Target Language.

\subsection{Reduction}

Of the 15 personification assemblies gathered, 6 translations were found using reduction techniques. Examples of the use of reduction techniques can be seen in the following table.

\begin{tabular}{|c|c|}
\hline Source Text & Target Text \\
\hline $\begin{array}{c}\text { Revenge impregnated with rain } \\
\text { and sun (P.3: B.6) }\end{array}$ & $\begin{array}{c}\text { A longing made pregnant by rain } \\
\text { and sunlight }\end{array}$ \\
\hline
\end{tabular}

The word on Source Text, it is implicit in Target Text. The use of reduction techniques to translate the personification sentence above right. Translators translate according to the norms in Target Language.

\section{Discussion}

The research data is in the form of personal personification sentences contained in five Indonesian poems and the translation is in English. The source of research data was obtained from a collection of June Rain poems by Sapardi Djoko Damono and their translations in John H. McGlynn's Before Dawn book.

Data in this study will be collected from Source Text and Target Text. The steps for collecting data in this study 
are the following; 1) Carefully read Source Text poetry, 2) Meaning of Source Text poetry to capture the intent or content contained in Source Text, 3) Carefully read Target Text poetry, 4) Search for personification in the 5 Source Text poems, 5) Search for translation of personification of 5 poems of Target Text, 6) Grouping the matching personifications of the Source Text and Target Text, 7) Grouping the personification of the unequalvalent Source Text and Target Text, and 8) Entering personification translation data into the data analysis table.

The purpose of this study is to explain to the reader about the techniques and methods that can be used to overcome the difficulties in applying the personification assembly in the poem in order to obtain an equivalent translation between Source Text and Target Text.

Translating the structure in poetry from Source Language to Target Language while maintaining its form, namely paying attention to stanzas and rhymes is indeed not an easy thing, the translator must give priority, which will be maintained, whether the content or the form. Regarding this, Larson divides the translation into two types.

There are two main kinds of translations. One is form based and other is meaning based. Form based translations attempt to follow the form of the source language and are known as literal translations. Meaning based translations make every effort to communicate the meaning of the source language text in the natural forms of the receptor language. Such translations are called idiomatic translations [19].

Translation is divided into two, namely translation based on form and translation based on meaning. Form-based translation is a translation that attempts to follow the source language form and is known as literal translation or literal translation. Whereas translation based on meaning is a translation that tries to convey Source Language meaning into Target Language form naturally. A translation like this is usually called idiomatic translation or idiomatic translation. In Larson's opinion, an interpreter can determine the way to translate a text according to the type of text to be translated.

Research on the translation of personification majors focuses on the types of personification speeches contained in the novel entitled Sekai no Chuushin de Ai wo Sakebu. Furthermore, the study analyzes the strategies used in the translation of the personification assembly [20].

From the study found four types of personification lectures: the personification of noun phrases, the personification of verb phrases, the personification of adjective phrases and personification of adverb phrases. From the results of the study found a translation strategy used in translating data including the strategy of translating the personification unit of Source Language into a BSf nonfigurative form, the strategy of translating the personification of Source Language into the personification form of Target Language.

If the previous study discussed the types of personification meetings that appeared in the novel titled Sekai No Chuushin De Ai Wo Sakebu by Katayama Koichi, in this study, the researcher will discuss the translation of the advanced personification in a collection of poems entitled June Rain by Sapardi Djoko Damono published in 2012 and the translation entitled Before Dawn by John H. Mc.Glynn published in the same year.

Personification Majors are disclosures by conveying inanimate or inanimate objects as if they were animate and possessing properties as possessed by humans. Myra Cohn Livingston reveals that the personification of the majors is an assembly that gives human traits to something which in fact does not have those qualities [21]. Dengan kata lain, personifikasi merupakan bagian dari bahasa kiasan yang menggambarkan benda-benda mati atau barang-barang yang tidak bernyawa seolah-olah memilki sifat manusia.

The following is a fragment of a poem by Sapardi Djoko Damono that uses personification.

Stop the rain.

Now the sun misses me,

lift the morning mist slowly

there is a throb in me

The equivalent in English is

I stopped the rain. Now the sun

In longing for me, slowly lifts the morning mist

Something beats

Inside myself.

In the fragment of the poem, inanimate objects are likened to animate as the characteristics possessed by humans, namely the word sun. The sun in the sentence above seems to have a feeling of longing. Even though the feeling of longing is human. To compare between Source Text and Target Text, the researcher rewrote another example of the personification of the Source Text and Target Text contained in the poem fragment entitled

Source Text personification progress:

Now the sun

In longing for me, slowly lifts the morning mist.

In the first line of the translation of the poem, there are differences in the number of words. Source Text only consists of two words, while the translation becomes three words. This means that there are additional words in the translation, namely the addition of the word. The word miss me is translated into in longing for me. Source Text consists of only one word, while the translation consists of four words. Lifting the morning mist slowly is interpreted to slowly lift the morning mist. In the translation, there was a transposition due to a change in Source Language structure into the Target Language structure.

In the translation of the personification majas in the poem changes in the number of words and changes in the structure of Source Language into Target Language. Therefore, this researcher wants to know whether in terms of the meaning of Source Text and Target Text it has comparability.

This research refers to techniques including: adaptation, amplification, borrowing, calibration, compensation, description, discursive creation, common equivalence, generalization, linguistic amplification, literal translation, modulation, particularization, subtraction, substitution, variation, and transposition [22].

\subsection{Adaptation Techniques (Adaptation)}

The technique of replacing cultural elements in Source Language with things that are the same in Target Language culture. This can be done because the cultural elements in Source Language are not found in Target Language. This technique is the same as the culture equivalent technique. For example, the expression as white as snow is replaced with the expression white as 
cotton, not as white as snow because snow is unknown in the target language.

\subsection{Amplification Techniques}

Translation techniques that explicitly or paraphrase an implicit information in Source Language. This technique is the same as exploiting and adding. Adding techniques are used to clarify an ellipsis expression, avoiding intimacy or ambiguity, adding connectors. Here are some examples of additional techniques, such as the word Ramadan, translated by the Muslim month of fasting.

\subsection{Borrowing Techniques}

In this technique, the translator borrows a word or phrase from the source language. Borrowing can be pure (pure borrowing) or naturalized loans (naturalized borrowing). The example of pure borrowing is hard disc which translates to hard disk, an example of naturalized borrowing is a computer that is translated into a computer.

\subsection{Calque Technique}

This technique is done by transferring words or phrases from Source Language literally to Target Language both lexically and structurally. Examples of the application of the Calque technique can be seen in the translation of the General-Explained-Explained Secretariat Phrase (M-D), translated as the secretary-general who is also an explained-explained pattern.

\subsection{Compensation Technique}

This technique introduces information elements or other stylistic effects in other places because it is not placed in the same position as in Source Text. Example: Never she visits her aunt translates to, the woman really has the heart not to meet her aunt.

\subsection{Technique Description (Description)}

This technique seeks to replace the term with a description of its shape or function. Example: the Italian word panettone is translated into a traditional Italian cake eaten during the new year. The translation technique is done because in English there is no known term or type of food Panetta, so it is considered to replace the noun with a description describing the type of food.

\subsection{Discursive Creation}

This technique is done by using a temporary equivalent that is out of context or unpredictable. In other words, translation techniques attempt to determine or create a temporary equivalent that is truly out of context that is not predictable. This is usually used in the translation of titles. For example, the title of the Malinkundang book was translated as A betrayed son of the Malinkundang.

\subsection{Common Equivalence Techniques (Established Equivalent)}

This technique is similar to literal translation. The difference is that this technique attempts to use terms that are commonly used in the dictionary or in the target language as the equivalent of Source Language. For example, the word effective translates to be effective.

\subsection{Generalization Technique (Generalization)}

This technique tries to find equivalents with more general or neutral terms in the target language. For example, becak (special) is translated as a vehicle (general).

\subsection{Linguistic Amplification Technique}

This technique seeks to add linguistic elements in Target Language so that the translation is longer. This technique is usually used in translation and dubbing. Example: I get it translated to let me pick up the phone.

\subsection{Linguistic Compression (Linguistic Compression)}

This technique attempts to synthesize existing linguistic elements to be simpler because they can be understood. For example, you must find out! be looking for!

\subsection{Literal Translation Techniques (Literal Translation)}

The technique of translating a word or phrase in words per word. For example, the sentence I will ring you translates to I will call you.

\subsection{Modulation Technique}

Translation techniques where the translator changes the point of view, the focus in Source Language; can be in structural or lexical forms. Example: air transportation is translated into a helicopter.

\subsection{Particularization Techniques}

Translation techniques that use more specific and concrete terms. This technique is the opposite of generalization. Example: Jewelry translates into a gold necklace.

\subsection{Reduction Technique}

This technique seeks to implicit information because its component meaning is included in the target language. Example: the month of fasting translates to Ramadan. Removal of the phrase the month of fasting for the translation of Ramadan nouns into English because the word is in Arabic and has the meaning of the month of fasting or 'fasting month' so that

\section{Conclude}

In translating literature, translators must have special expertise in the field of literature. Regarding the translation of poetry as a literary work, the translator's 
ability to be able to express messages in the Source Text into the Target Text without reducing the beauty of the form of the Source Text will be highly tested. The beauty of language, rhythm, figurative expressions and imagery created by poets in conveying their ideas, ideas, feelings, and mandates need to be studied in depth by the translator.

To be able to convey the poet's message without reducing the beauty of the poem, the accuracy of the translator in determining the translation techniques that will be used. The use of translation techniques will affect the comparability between Source Text and Target Text. The following is a table on the use of translation techniques and the level of compatibility obtained:

\begin{tabular}{|c|c|c|}
\hline NO & Technique & Worth it / not worth it \\
\hline 1 & Transposition & 11 Equalvalent \\
\hline 2 & Amplification & $\begin{array}{c}15 \text { Equalvalent } \\
2 \text { Not Equalvalent }\end{array}$ \\
\hline 3 & Reduction & 6 Equalvalent \\
\hline
\end{tabular}

From the table above, it can be concluded that the translator is quite observant in choosing translation techniques to obtain a high level of equivalence. Thus it can be said that there is a connection between translation techniques and equivalence.

\section{References}

[1] George Steiner, After Babel: Aspects of Language and Translation. New York, NY: University Of Oxford, 1998.

[2] E. Janfaza, A. Assemi, and S. S. Dehghan, "Language, Translation, and Culture,” Int. Conf. Lang. Medias Cult., vol. 33, pp. 83-87, 2012.

[3] H. M. El-dali, "Towards an understanding of the distinctive nature of translation studies,” J. King Saud Univ. - Lang. Transl., vol. 23, no. 1, pp. 29-45, 2011.

[4] Tamás Kiss Csilla Weninger, "Cultural learning in the EFL classroom: the role of visuals,” ELT J., vol. 71, no. 2, 2017.

[5] V. Heyl and M. Hintermair, "Executive Function and Behavioral Problems in Students with Visual Impairments at Mainstream and Special Schools,” no. August, pp. 251-264, 2015.
[6] A. S. Moore, Jason; Schleppegrell, Mary; Palincsar, "Discovering Disciplinary Linguistic Knowledge with English Learners and Their Teachers: Applying Systemic Functional Linguistics Concepts through Design-Based Research,” Eric J., vol. 52, no. 4, p. 28, 2018.

[7] S. A. Shirinzadeh, T. Sepora, and T. Mahadi, "Translating Proper Nouns: A Case Study on English Translation of Hafez's Lyrics,” Can. Cent. Sci. Educ., vol. 7, no. 7, 2014.

[8] S. Meihua, "Choice-Making in Rendering Culture-Bound Elements in Literary Translation: A Case Study on the English Translation of 《灵魂像风》,” Can. Cent. Sci. Educ., vol. 7, no. 10, 2014.

[9] R. A. Valeeva and I. N. Martynova, "Rendering of Foreign Language Inclusions in the Russian Translations of the Novels by Graham Greene,” Int. J. Environ. Sci. Educ., vol. 11, no. 8, pp. 1863-1875, 2016.

[10] B. Nash, ““'But Isn’t the Teacher Supposed to Tell Us?”: Illuminating Transactional Reading Processes Through Transmediation," J. Lang. Lit. Educ., vol. 14, no. 2, pp. 1-11, 2018.

[11] W. Hurren, "with a poem instead of beginning with a poem, because I worry that if I start with a poem, students will be wondering," Can. Soc. Stud., vol. 50, no. 1, pp. 1-11, 2018.

[12] Amrita Sharma, "Conceptualization and Linguistic Expression: Using Religious Poetry in ELT,” Adv. Lang. Lit. Stud., vol. 5, no. 5, 2014

[13] E. O. Bean and K. R. Brennan, "Youth Voices: Performance Poetry as a Platform for Literacy, Creativity, and Civic Engagement," J. Appl. Res. Child. Informing Policy Child. Risk, vol. 5, no. 1, 2014.

[14] I. W. Dirgeyasa, "The Effort to Increase the Students , Achievement in Poetry Mastery through Semiotic Method," Adv. Lang. Lit. Stud., vol. 8, no. 1, 2017.

[15] A. L. Freyn and D. Ed, "Effects of a Multimodal Approach on ESL / EFL University Students' Attitudes towards Poetry,” J. Educ. Pract., vol. 8, no. 8, pp. 80-83, 2017.

[16] L. Venuti, he Translator's Invisibility. London: Routledge., 2018.

[17] P. Newmark, A textbook of translation. Hong Kong: Pearson Education Limited, 1987.

[18] C. T. Eugene Nida., The Theory and Practice of Translation. Leiden: J.E Brill, 1974.

[19] Mildred L. Larson, Meaning Based Translation. New York, NY: University Press of America, 1984.

[20] N. P. L. W. dan I. G. O. Ni Luh Jessica Pratiwi, "Penerjemahan Majas Personifikasi dalam Novel Sekai no Chuushin De Ai Wo Sakebu,” J. Hum. Ilmu Budaya Unud, vol. 20, pp. 162-167, 2017.

[21] Myra Cohn Livingston, Poem Making. New York: HarperCollins, 1991.

[22] Lucia Molina \& Amparo Hurtado Albir, "Translation Technique Revisited: A Dynamic and Functionalist Approach,” Prousiding, vol. 47, no. 4, p. 509, 2002. 